УДК 78.01+781.6
DOI https://doi.org/10.31723/2524-0447-2020-30-2-21

Ірина Мар'янівна Шиитальна

ORCID: 0000-0001-8558-0259

аспірант кафедри історії музики та музичної етнографії

Одеської національної музичної академії імені А. В. Нежданової

iryna.shpytalna@gmail.com

\title{
МУЗИЧНО-ВИКОНАВСЬКА КОМУНІКАЦІЯ ЯК КОГНІТИВНИЙ ФЕНОМЕН: АКТУАЛЬНІ ПІДХОДИ ТА ОЦІНКИ
}

Мета роботи полягає в розкритті когнітивних засад виконавського стилю у сфері акордеонної творчості, визначенні якісно нових творчих методів виконавства, предметних рівнів когнітивної інтерпретації, що зумовлює художньо-психологічний аналіз постаті виконавия як твория нових смислів у різних творчих комунікативних ситуаціях, образно-емоційному й онтологічному аспектах поведінки. Це приводить до потреби формування поняття когнітивного стилю виконавського мислення, яке охоплює розумові, емоційно-вольові, творчі акти свідомості, за допомогою яких виконавець втілюе технічні та художньо-філософські завдання на різних рівнях виконавської діяльності. Методологія дослідження передбачає поєднання інтердисциплінарного та феноменологічного підходів, що дозволяє більш детально розглянути когнітивні засади виконавської творчості, зокрема розширити сферу вивчення акордеонного виконавства з позицій епістемології, психології та музикознавства. Наукова новизна дослідження визначається запровадженням когнітивно-комунікативного підходу у виконавській діяльності як одного із провідних; формуванням когнітивного виконавського стилю, його обгрунтуванням в акордеонній творчості на прикладі сучасного репертуару та його змістової наповненості. Центральне місце у формуванні когнітивного виконавського стилю належить процесам мислення та свідомості виконавия, які корелюються із практичними діями і певним чином залежать від отриманого досвіду. Висновки статті дозволяють визначити психологічний когнітивно-комунікативний підхід як один із провідних у формуванні інтерпретаційного мислення виконавия-акордеоніста, виявити творчі методи та їхні засади в акордеонній виконавській творчості. Дані психологічні підходи і творчі концепції спрямовують до визначення когнітивного стилю виконавського мислення як актуальної категорії сучасного акордеонного виконавства.

Ключові слова: мислення, акордеонна виконавська творчість, інтерпретація, музичні когніції, творча комунікація, когнітивно-комунікативний підхід, когнітивний виконавський стиль.

(c) Шпитальна I. M., 2020 
Shpytalna Iryna Mar'ianivna, Graduate Student at the Department of Music History and Musical Ethnography of the Odessa National A. V. Nezhdanova Academy of Music

Musical and performing communication as a cognitive phenomenon: current approaches and evaluations

Research objective. The purpose of the article is to reveal the cognitive principles of performing style in the field of accordion art, to determine qualitatively new creative methods of performance, subject levels of cognitive interpretation, which determines the artistic and psychological analysis of the performer as the Creator of new meanings in various creative communicative situations figurative-emotional and ontological aspects of behavior. This leads to the need to form the concept of cognitive style of performing thinking, which includes mental, emotional, creative acts of consciousness, through which the performer embodies technical and artistic and philosophical tasks at different levels of performance. The methodology involves a combination of interdisciplinary and phenomenological approaches, which allows to consider in more detail the cognitive principles of performance, in particular to expand the study of accordion performance from the standpoint of epistemology, psychology and musicology. The scientific novelty of the study is determined by the introduction of a cognitive-communicative approach in performance as one of the leading; formation of cognitive performing style, its substantiation in accordion creativity on the example of modern repertoire and its content. Central to the formation of cognitive performance style are the processes of thinking and consciousness of the performer, which correlate with practical actions and in some way depend on the experience. Conclusions. The conclusions of the article allow to define the psychological cognitive-communicative approach as one of the leading ones in the formation of interpretive thinking of an accordionist, to reveal creative methods and their foundations in accordion performance. These psychological approaches and creative concepts lead to the definition of cognitive style of performing thinking as a relevant category of modern accordion performance.

Key words: thinking, accordion performance, interpretation, musical cognitions, creative communication, cognitive-communicative approach, cognitive performance style.

Шпытальная Ирина Марьяновна, аспирант кафедры истории музыки и музыкальной этнографии Одесской национальной музыкальной академии имени А. В. Неждановой

Музыкально-исполнительская коммуникация как когнитивный феномен: актуальные подходы и оценки

Цель работы заключается в раскрытии когнитивных основ исполнительского стиля в сфере аккордеонного творчества, определении качественно новых творческих методов исполнения, предметных уровней когнитивной интерпретации, что приводит к художественно-психологическому анализу личности исполнителя как твориа новых смыслов в различных творческих коммуникативных ситуациях, образно-эмоциональном и онтологическом аспектах поведения. Это приводит к необхо- 
димости формирования понятия когнитивного стиля исполнительского мышления, которое охватывает умственные, эмоционально-волевые, творческие акты сознания, с помощью которых исполнитель воплощает технические и худохественно-философские задачи на разных уровнях исполнительской деятельности. Методология исследования предполагает сочетание интердисциплинарного и феноменологического подходов, что позволяет более детально рассмотреть когнитивные основы исполнительского творчества, в частности расширить сферу изучения аккордеонного исполнительства с позиций эпистемологии, психологии и музыковедения. Научная новизна исследования определяется введением когнитивно-коммуникативного подхода в исполнительской деятельности как одного из ведущих; формированием когнитивного исполнительского стиля, его обоснованием в аккордеонном творчестве на примере современного репертуара и его содержательной наполненности. Центральное место в формировании когнитивного исполнительского стиля занимают процессы мышления и сознания исполнителя, которые коррелируются с практическими действиями и определенным образом зависят от полученного опыта. Выводы статьи позволяют определить психологический когнитивно-коммуникативный подход как один из ведущих в формировании интерпретационного мышления исполнителя-аккордеониста, проявить творческие методы и их основы в аккордеонном исполнительском творчестве. Данные психологические подходы и творческие концепции направляют к определению когнитивного стиля исполнительского мышления как актуальной категории современного аккордеонного исполнительства.

Ключевые слова: мышление, аккордеонное исполнительское творчество, интерпретация, музыкальные когниции, творческая коммуникация, когнитивно-коммуникативный подход, когнитивный исполнительский стиль.

Актуальність теми дослідження. Мистецтво, зокрема музика, на сучасному етапі розвитку потребує комплексного вивчення, 3 використанням інтердисциплінарного підходу, який об'єднує методи різних галузей і модифікує їх або створює якісно новий метод. Виконавську творчість, зокрема акордеонну, можна розглядати з позицій когнітивної науки, оскільки предметом останньої є процес пізнання, формування системи знань. Когнітивна наука вивчає та моделює процеси, пов'язані з мисленням, зокрема вивчає сприйняття, пам'ять, увагу, розум, емоції. Вивчення когнітивної діяльності спирається на наукові результати, отримані у психології, лінгвістиці, філософії, гносеології, епістемології. Проте такий підхід вимагає попереднього аналізу цих результатів з погляду їхньої доцільності та відповідності в музичному виконавському мистецтві. 
Виконавська акордеонна творчість на даному етапі розвитку є окремою галуззю вивчення і вимагає пошуку нових актуальних підходів, які б стали основою для більш детального розгляду творчої особистості виконавця-акордеоніста, процесів його мислення, формування специфічних професійних домінант, якими визначається когнітивно-комунікативна спрямованість його діяльності. Але для того, щоб визначити когнітивну модель творчого процесу виконавця, необхідно попередньо виявити основні художні завдання сучасного виконавця-акордеоніста, які у зв'язку з удосконаленням органологічних особливостей інструмента значно розширились та потребують музикознавчого переосмислення.

Теоретичну базу, що охоплює питання вивчення генези та розвитку акордеонної виконавської творчості, репертуарних жанрово-стильових показників, становлять праці відомих педагогів та музикознавців: А. Басурманова, В. Бесфамільнова, М. Давидова, І. Сргієва, І. Іванова, М. Імханицького, В. Марченка, А. Мірека, М. Оберюхтіна, А. Онуфрієнка, А. Сташевського, О. Спешилової, А. Черноіваненко й інших. Однак психологічні засади виконавського стилю акордеонної творчості малодосліджені.

Мета дослідження полягає в розкритті психологічних когнітивних засад виконавського стилю у сфері акордеонної творчості, визначенні творчих когнітивних методів акордеонного виконавства, що зумовлює психологічний аналіз постаті виконавця в різних творчих комунікативних ситуаціях. Процес виконавської творчості визначається категорією музичних когніцій як сукупністю психологічних процесів мислення, сприйняття, здібностей, уяви, творчих настанов. Музичні когніції в даному контексті пов'язані із професійною творчою діяльністю виконавця та специфікою акордеонного мистецтва.

Виклад основного матеріалу. Акордеонна виконавська творчість вражає своєю багатогранністю, широтою художньо-виражальних засобів, всеосяжністю тембро-сонорних можливостей. 3 одного боку, це симфонічність, оркестровість, масшабність, гучність, а з іншого - здатність до інтроспекції, до представлення внутрішнього голосу свідомості, образів тиші, спокою.

Ця семантична двоїстість висуває перед виконавцем-акордеоністом завдання іншого рівня та значення. До провід- 
них художніх завдань можемо віднести процес розуміння й інтерпретації, індивідуальне прочитання композиторського тексту, виявлення тембросемантики акордеона в різних жанрово-стильових показниках та напрямах (бароко, класицизм, романтизм), іманентної тембро-сонорної сутності сучасного акордеона, вираження найтонших психологічних станів за допомогою сучасних технічних засобів.

За М. Бахтіним, кожна особистість посідає своє єдине унікальне місце у світі, який є предметом учинку: учинку-думки, учинку-почуття, учинку-слова, учинку-справи. Думка породжує ідею, задум; почуття - емоції; слово - пізнання, розуміння; справа - твір, інтерпретацію, процес слухання, сприймання. Отже, будь-яке діяння (вербальне - невербальне; духовне фізичне) може стати творчим актом, який охоплює переживання, прагнення, дію в різних комунікативних ситуаціях.

Виконавець бере безпосередню участь у комунікативно-творчому акті, реалізовує свою особистість у творчому процесі. Багато дослідників, зокрема М. Арановський, відзначали комунікативність музичного мистецтва, де «твір - як комунікат, повідомлення, яке передає композитор слухачу». Музикознавець позначає цю сторону музичної діяльності як семантичну, оскільки iї основна функція - передача особливої інформації, що закладена у тексті. «Музика постає як набір специфічних каналів комунікації» [12, с. 357.] Постать виконавця в цьому процесі посідає одне із центральних місць і визначається комунікативною ситуацією, у якій він бере участь. Такі комунікативні ситуації можуть бути пов'язані із зовнішніми і внутрішніми чинниками, часовими та просторовими умовами, сольною й ансамблевою грою. До зовнішніх чинників відносимо ситуативні умови виконання (концертний зал, акустичні особливості, творча налаштованість публіки до сприйняття музичного твору); до внутрішніх - художні внутрішньомузичні чинники, жанрово-стильові умови музики, здатність до трансцендентального переживання, індивідуалізації, злиття свідомого та несвідомого, вихід за межі власної особистості.

В акордеонному виконавстві теж можемо спробувати з'ясувати комунікативні ситуації, у яких бере участь виконавець-акордеоніст:

- за напрямами (академічний, естрадно-джазовий, авангардний тощо); 
- за емоційно-естетичною спрямованістю, образними векторами (драматичний, ліричний, трагічний, епічний);

- за кількістю учасників комунікації (сольне, ансамблеве, оркестрове виконавство);

- за адаптацією музичного тексту до технічних особливостей акордеона (оригінальна музика; баянна музика, яка теж потребує адаптації; перекладення, транскрипція авторська/ композиторська або власна).

Дані комунікативні ситуації набувають рис когнітивного творчого спілкування, оскільки породжують особливу інформацію з новими особистісними смислами. Вона виражена через інтерпретацію, зумовлену індивідуальними стильовими рисами композиторської та виконавської творчості. Курт Закс відзначав, що «стиль мистецтва - дзеркало людини, яке має необмежену свободу і ніколи не повторює себе <...> Нема тут тривожного прогресу, який прагне до кінцевої досконалості. Але є тут дещо краще, ніж прогрес: безперервна, завжди нова адаптація мистецтва до перемінливих потреб людини» [12, с. 27].

Така адаптація відбувається не тільки в мистецтві, але й у виконавській акордеонній творчості. Це певне пристосування виконавця-акордеоніста до особливостей органології інструмента, його іманентної інтонаційної сутності, тембросемантики в оригінальному репертуарі, до використання специфічних тембро-сонорних ефектів, тобто до нових темпоральних змін, пов'язаних із виходом акордеона на зовсім інший органологічний, технічний та виконавський рівень. Це дозволяє розширювати коло художніх виконавських завдань, підвищує семантичну наповненість. Відповідно, акомодаційні процеси, зокрема у виконавському мистецтві, завжди передбачають когнітивність, тобто пізнавальність та інформаційність, яка рухається в зустрічному напрямку, «композитор - виконавець - слухач».

Сприйняття музики як психологічної категорії передбачає модифікацію поняття «когнітивний», оскільки передбачає процес розуміння, тому й пошук способів вирішення проблем у певній ситуації. Процес акордеонного виконавства постає як акт пізнання й усвідомлення історичних передумов формування стабільних компонентів музичної мови; стильових, жанрових, структурних особливостей твору певної епохи; індивідуального композиторського мислення, а також поро- 
дження нових смислових зв'язків. Отже, ми можемо говорити про сукупність музичних «когніцій», які включають в себе певні знання, способи усвідомлення, мислення, творчі настанови, здібності, наприклад уяву, та інше. Н. Іванюк пояснює, що когніція як об'єкт когнітології поділяється на різні процеси, кожний з яких пов'язаний із визначеною когнітивною здібністю, однією з яких є здібність говорити. Когніція - це сприйняття світу, спостереження і категоризація, і мислення, і мова, і уява, інші психічні процеси в їх поєднанні. У даному контексті музичні виконавські когніції зумовлені комунікативними ситуаціями і завданнями, пов'язаними із професійною творчою діяльністю.

Когнітивний підхід у виконавській акордеонній творчості передбачає іiі вивчення як комплексного осмислення звукової дійсності та іiі вираження в індивідуалізації, що зумовлює пошук спеціальної когнітивно-виконавської стратегічної моделі. Вона створюється для втілення ціннісних творчо-індивідуальних виконавських завдань, упредметнення унікального стильового виконавського простору, який включає розуміння історичних передумов композиторської творчості, знання жанрово-стильових чинників, засвоєння акордеонного репертуару (власні виконавські транскрипції та переклади), а також індивідуальне прочитання музики, з урахуванням особливостей інструмента. Виконавець стає творцем нових смислових значень, реалізованих у безпосередньому акордеонному звучанні.

Це комплекс взаємопов'язаних операцій, який є основою діяльності виконавця і може бути розширений. Отже, можемо спробувати виділити такі когнітивні рівні виконавської діяльності:

- формально-функціональний (ідентифікація музичного тексту на знаковому рівні, з урахуванням засобів музичної виразності, стабільних та мобільних компонентів тексту);

- семіологічно-структурний (значення окремих сегментів у контексті цілого);

- контекстуально-текстологічний (віднайдення, уточнення і збагачення основного смислу, закладеного композитором);

- комунікативно-пізнавальний (передача специфічної інформації шляхом безпосереднього відтворення, утілення музично-образних параметрів смислу).

Загалом виконавська творчість вимагає постійної системності у практичній діяльності й обміну досвідом. Дія та дос- 
від взаємопов'язані та взаємозалежні один від одного. Адже тільки виконанням визначених логічних операцій ми отримуємо досвід глибшого розуміння, пізнання. У. Матурано вважав, що «будь-яка дія є пізнання, всяке пізнання є дія» $[10$, c. 6$]$.

Цінність досвіду, який передає мистецтво, визначається не його новизною, але тим, як воно виявляє скриті рівні і плани внутрішнього життя слухача і залежно від цього формує його внутрішнє інтелектуальне, емоційне, чуттєве, духовне середовище [11, с. 356]. Треба сказати, що мистецтво виявляє скриті рівні не тільки слухача, але й виконавця, як посередника комунікації.

Виконавець-акордеоніст реалізується у творчому процесі, керується когнітивним простором поведінки, що визначається морально-естетичними настановами, а також категорією відповідальності за вибори та вчинки. Він постає як творець-інтерпретатор і як особистість. Його поведінку можна розглядати в образно-емоційному (поведінка на сцені, манери, артистизм, естетичний комплекс зовнішніх проявів) та онтологічному (поведінка в житті, морально-естетичні настанови, ціннісні орієнтації) аспектах. Звідси виникають категорії щирості, відкритості, душевності, емоційності та їхня взаємозалежність у цих двох вимірах. Як писав М. Бахтін, «мистецтво і життя не одне, але має стати єдиним у сукупності моєї відповідальності».

Яскравим прикладом такого зближення мистецтва і життя в акордеонній творчості може стати сюїта «Гаїті» Ф. Анжеліса, що написана у 2010 р. Твір присвячений пам'яті П'єтро Марі, племіннику Ф. Анжеліса, який загинув у 2010 р. на острові Гаїті внаслідок найсильнішого землетрусу XXI ст.

Композитор застосував новаторські виконавсько-технічні прийоми, які передають характер музики та трагедійно-смислову наповненість.

У тематичному викладі матеріалу спостерігається медитативність, багатоповторюваність, що асоціюється з безвихідністю. Емоційна напруга, драматизм поступово збільшуються через засоби музичної виразності - динамічні нюанси, міхові штрихи, фактуру, тембри.

Композитор використовує міхові прийоми гри - тремоло, рикошет; для передачі смислового наповнення застосовує динамічні, штрихові та темброві контрасти. В оригінальній 
тембросемантиці акордеона (баяна) він знаходить новаторський когнітивний підхід до вираження людської трагедії у високому філософському тлумаченні звукової матерії. Адже мистецтво, зокрема музика, не бере матеріал із життя, але $є$ натхненним ним. Завдяки цьому відбувається діалог мистецтва та життя, простору та часу, неба та землі.

У даному творі можемо спостерігати когнітивний підхід, що зумовлений реальними трагічними подіями, ставленням автора до них, а також особливим місцем виконавця-акордеоніста в комунікативній ситуації втілення трагізму за допомогою тембрової семантики та сучасних тембро-сонорних акордеонних ефектів.

Тембросемантика акордеона у класичному (бароко, класицизм, романтизм) і оригінальному сучасному репертуарі демонструє універсалізм тембрового амплуа цього інструмента, широкі можливості втілення засобами акордеонної гри найрізноманітніших естетичних пластів музики - від комічно-гротескного до трагічного, від ліричного до драматичного, від земного до піднесеного.

Це зумовлює пошук нових підходів до сучасного акордеонного виконавства, серед яких:

1. Історико-стильовий - вибір виконавської інтерпретації з урахуванням особливостей історичної епохи, національної школи, іiі жанрово-стильових традицій та пристосуванням до них технічних і виконавських можливостей інструмента.

2. Акомодаційно-органологічний - музичний текст виконується відповідно до виконавських і технічних можливостей інструмента (наприклад, застосування регістрової техніки у клавірній музиці).

3. Інтеграційний - об'єднання історико-стильового й акомодаційно-органологічного підходів, що $є$ найбільш оптимальним для пошуку творчої інтерпретації з урахуванням жанрово-стильових особливостей музики та іiі адаптації до можливостей інструмента.

Як бачимо, виконавська творчість є складним творчим процесом, який охоплює технічні та художні завдання та вимагає постійної роботи мислення; адже саме воно вибудовує індивідуальну модель розуміння, сприйняття світу, зокрема у виконавській творчості - розрізняє комунікативні ситуації, поведінку в образно-емоційному й онтологічному аспектах, спрямовує до осмислення звукової дійсності. 
Мислення - це процес духовної діяльності виконавця, який спрямований на породження індивідуальних творчих ідей. Духовне мислення будемо розуміти як розумову діяльність виконавця у процесі інтерпретації.

Отже, можемо спробувати визначити когнітивний стиль виконавського мислення як сукупність розумових, емоційно-вольових, творчих актів свідомості, за допомогою яких виконавець виконує художні завдання та втілює їх у процесі інтерпретації.

Когнітивний стиль виконавської інтерпретації - цілісний психологічний процес, що передбачає взаємодію та перетворення всіх складових частин особистісної свідомості у спрямуванні до образно-звукового відтворення змісту музики. Даний стиль передбачає виникнення нової єдності фізіологічних, емоційних, інтуїтивних, прогностичних особливостей мислення виконавця, реалізацію його художніх естетичних смаків, експлікацію розуміння жанрово-стильових засад музики.

Когнітивний стиль виконавської інтерпретації зумовлює розроблення творчих методів та основоположних принципів акордеонного виконавства. Це дозволяе визначити предметні рівні когнітивної інтерпретації:

1) автентичний рівень визначається як відповідність глибинного проникнення, буквального відтворення і розуміння смислу, реконструйоване звучання творів минулого, кореляція сучасних виконавських засобів із жанрово-стильовими особливостями історичної епохи. Даний рівень визначає змістову автентику як обов'язкову складову частину виконавської інтерпретації. Виконання автентичної музики вимагає когнітивних знань особливостей композиторської творчості, національної школи тощо. Даний тип інтерпретації може співвідноситись 3 історично-стильовим підходом акордеонного виконавства;

2) оригінально-особистісний рівень визначається як власний внесок у творчому процесі виконавської інтерпретації, духовно-практичне діяння виконавця в пошуку ціннісних індивідуальних орієнтирів, їх вираження у звуковій матеpii. Виконавець-акордеоніст є творцем нових особистісних смислів, центральне місце водночас посідає власне прочитання музичного твору, індивідуальна еманація історичних стильових ідей. 
Виконавсько-інтерпретативна діяльність, зумовлена процесами мислення, передбачає формування духовного стану виконавця, який є носієм вищих естетичних емоцій та почуттів. За М. Бонфельдом, «мислення перебуває в безпосередньому зв'язку з мотивуючою сферою психіки, сферою емоцій, афектів, захоплень» [6, с. 114]. Це дозволяє пропонувати образно-експресивну модель, яка охоплює складні синтетичні стани, очолені емоційно-естетичною реакцією. Звідси можемо говорити про творчу емфатичну ситуацію, яка характеризується підвищеною емоційною чутливістю виконавця на всіх когнітивних рівнях його діяльності, що може призводити до зіткнення душевного стану з раціональними історичними твердженнями, а образно-естетичної моделі - із предметними рівнями когнітивної інтерпретації.

Творча емфатична ситуація у виконавському мистецтві може визначатись такими психологічними станами, як настрій, переживання, почуття.

Настрій - це творчо-емоційний стан, який передбачає постійне прагнення до мистецтва і визначається ситуативно-контекстуальними чинниками, а саме умовами виконання твору і змістом та характером звукового матеріалу. М. Арановський називає такий психологічний стан екстрамузичним стимулом. За автором, це будь-який психічний імпульс, який викликає процес творчості, творчого настрою, готовність створювати.

Процес творчості визначає переживання/співпереживання, що постає як внутрішній емоційний стан виконавця, який проявляється в онтологічному й образно-естетичному аспектах поведінки (у побуті та на сцені). Г. Гадамер розглядає етимологію слова «переживати» у двох напрямах. Спочатку воно означало «бути ще живим, коли щось трапилось». Звідси пережите - це завжди особисто пережите. Проте також використовувалась форма «пережите», яка означала збережений зміст того, що пережито. Таке значення постає як результат, який підсумовує тривалість і значення пережитої події. Отже, одним з основних завдань виконавця є духовне, емоційне «пережиття» музичного твору, співпережиття композиторському задуму і породження нових особистісних смислів. Особистісне переживання виражається в емоційно-образній формі, тому пов'язане з перетворення емоцій і новим змістовим наповненням звукового образу. 
Відповідно виникає поняття емотивного мислення, яке може виступати як один зі способів інтерпретаційного мислення і $€$ необхідною складовою частиною когнітивного стилю виконання. Але під емотивним мислення розуміємо не звичайні емоції, а складні амбівалентні емоції, які є інтегральними показниками діяльності людської свідомості. Амбівалентні емоції виражають двоїстість явищ зовнішнього і внутрішнього світів виконавця, єдність свідомого і несвідомого, суперечливі стани поведінкової й емоційної сфер. В акордеонному виконавстві це може проявлятись у суперечливості індивідуального прочитання музичного тексту, зіткненні змістових сфер драматичного і ліричного, піднесеного та земного.

Категорія особистісного емотивного мислення виконавця мотивується потребами вищих почуттів, ціннісних естетичних, моральних орієнтацій. Почуття в даному контексті можемо інтерпретувати як набір специфічних когнітивних переживань виконавця, спричинених об'єктивною дійсністю й особистим ставленням до світу.

Загалом творча емфатична ситуація постає як результат мислення й акт пізнання і визначається духовно-емоційними психологічними станами. Це зумовлює емоційний зміст виконавської інтерпретації, а звідси і когнітивного стилю.

Процес сценічного виконання $є$ яскравим прикладом творчої емфатичної ситуації, яка виступає в сукупності когнітивних процесів інтерпретативного мислення, трансцендентальної участі свідомості та прояву творчого настрою / особистісного переживання / індивідуального почуття. Усі ці процеси зумовлені контекстом музичного матеріалу та рівнем когнітивної готовності виконавця до творчої діяльності. Як вище зазначалось, сюїта «Гаїті» Ф. Анжеліса є прикладом співвідношення людських переживань, звукового драматизму й емоційної напруги. Психологічно-емоційний внутрішній стан виконавця має відповідати характеру музику.

Сюїта складається із трьох взаємопов'язаних за смислом частин. Основна ідея твору - звукове відображення землетрусу та втілення психологічно-емоційних людських станів, тобто кореляція зовнішніх трагічних подій та стану внутрішньої людської свідомості.

Перша частина твору починається в партії лівої руки, динаміка pp, ритмічний малюнок підкреслює тривогу та набли- 
ження небезпеки. Маркатний штрих викликає аналогію з віддаленими поштовхами.

Для передачі смислу музики композитор використовує сучасні технічні прийоми акордеонної гри (тремоло, рикошет, вібрато, ритмічні удари по корпусу інструмента), динамічні, штрихові та темброві контрасти. Відштовхуючись від контексту твору, можемо провести аналогію із потужними раптовими поштовхами землетрусу і більш слабкими.

Друга частина сюїти написана в низькому регістрі, тонально нестійка, має перемінний метр, що властиво творчості Ф. Анжеліса. Вражає експресивністю та чуттєвістю. Композитор використовує міховий прийом гри - тремоло, що знову ж таки викликає асоціації з поштовхами землетрусу, тільки вже набагато інтенсивнішими, ніж у першій частині.

Третя частина $є$ більш віртуозною та різноплановою, хоча знову спостерігається медитативність, яка спрямовує слухача до зосереджено-поглибленої вдумливості, споглядальності, самоаналізу.

Дуже експресивним є фрагмент з каденцією. Він вражає яскравим тематизмом, динамічним стрімким розвитком, гармонічною структурою.

Заключний розділ наповнений трагічними інтонаціями скорботи, смутку, відчуження передає глибоке психологічно-емоційне напруження. Знову з'являються віддалені удари по лівому корпусу, однак усе поступово завмирає, затихає, зупиняється.

Пропонуємо схарактеризувати провідні емоційні стани (позитивні та негативні) та засоби музичної виразності, сучасні прийоми акордеонної гри, з якими вони пов'язані в контексті даного твору. До позитивних емоційних станів віднесемо надію - віру - емпатію. Надія співвідноситься 3 матеріалом каденції, а саме яскравим тематичним та гармонічним розвитком. У даному фрагменті відголоски теми як віддалені поштовхи, звідси надія на життя. Віра визначається багатоповторюваністю, на якій побудований музичний матеріал твору. Віра завжди породжує молитовну лінію, релігійну медитацію, злиття двох особистостей - людської та божественної. Емпатія є ключовим моментом трагедії. Адже тільки якщо співпереживаємо, ми можемо пережити складні трагічні ситуації. У контексті сюїти процес співпереживання характеризується накладення тематичного матеріалу з підголосковим матеріалом (тт. 58-73). 
До негативних емоційних станів віднесемо страх - тривогу - відчай. Страх визначається психологічної невизначеністю, а саме маркатними штрихами, динамічними контрастами. Тривога постає як передчуття небезпеки, інтуїтивний стан свідомості. Визначається розвитком кульмінаційних моментів, які характеризуються посиленням емоційної напруги, драматизму за допомогою фактурного наповнення та філірування динамічних нюансів. Відчай проявляється в розумінні власного безсилля та невідворотності ситуації, яка має трагічні наслідки для певної частини людства. У творі яскравим прикладом відчаю $є$ поштовхи, які автор передає за допомогою міхових прийомів (тремоло, рикошет).

Отже, у даній сюїті простежується специфічне співвідношення когнітивних психологічних засад виконавця і створення творчої емфатичної ситуації з характерними для неї складниками. Можемо говорити, що даний приклад засвідчує особливий композиційний шлях до втілення когнітивного стилю виконавської інтерпретації.

Висновки статті дозволяють визначати когнітивно-комунікативний підхід як один із провідних у формуванні інтерпретаційного мислення виконавця та його складових частин, у виявленні творчих методів та їхніх художньо-психологічних засад в акордеонній виконавській творчості. Дані психологічні підходи і творчі концепції спрямовують до визначення когнітивного стилю виконавського мислення як актуальної категорії сучасного музичного виконавства.

\section{СПИСОК ЛІТЕРАТУРИ}

1. Символ. Софія-Логос : словник / С. Аверінцев. Київ : Дух і Літера, 1999. С. 154-159.

2. Арановский М. Мышление, язык, семантика. Проблемы музыкального мышления / сост. и ред. М. Арановский. Москва : Музыка, 1974. С. 90-128.

3. Арановский М. Музыкальный текст. Структура и свойства. Москва : Композитор, 1998, 343 с.

4. Бахтин М. Автор и герой в эстетической деятельности. Эстетика словесного творчества / М. Бахтин ; сост. С. Бочаров ; прим. С. Бочарова, С. Аверинцева. 20-е изд. Москва : Искусство, 1986. C. $9-191$.

5. Бахтин М. Эстетика словесного творчества / сост. С. Бочаров ; прим. С. Аверинцева, С. Бочарова. 2-ое изд. Москва : Искусство, 1986. $445 \mathrm{c}$. 
6. Бонфельд М. Музыка. Язык. Речь. Мышление : опыт системного анализа музыкального искусства. Ч. 1. Тезисы. Москва : МГЗПИ, 1991. $125 \mathrm{c.}$

7. Выготский Л. Психология искусства. Москва : Искусство, 1968, 576 c.

8. Выготский Л. Мышление и речь. 5-е изд., испр. Москва : Лабиринт, 1999, $352 \mathrm{c.}$

9. Гадамер Х.-Г. Истина и метод. Основы философской герменевтики. Москва : Прогресс, 1988. 637 с.

10. Матурана У., Варела Ф. Древо познания : Биологические корни человеческого понимания. Пер. с англ. Ю. Данилова. Москва : Прогресс-Традиция, 2001. 224 с.

11. Мартинюк А. Словник основних термінів когнітивно-дискурсивної лінгвістики. Харків : ХНУ імені В.Н. Каразіна, 2011, 196 с.

12. Орлов Г. Древо музыки. 2-ое изд. Санкт-Петербург : Композитор, 2005, 440 с.

\section{REFERENCES}

1. Averintsev, S. (1999) Symbol. S.S. Averintsev. Sofia-Logos. Vocabulary. K.: Spirit and Letter. P. 154-159.

2. Aranovsky, M. (1974) Thinking, language, semantics. Problems of musical thinking: comp. And order. M. Aranovsky. M.: Music. P. 90-128.

3. Aranovsky, M. (1998) Musical text. Structure and properties. M.: Composer. $343 \mathrm{p}$.

4. Bakhtin, M. (1986) Author and hero in aesthetic activity. M.M. Bakhtin. Aesthetics of verbal creativity. 20'th ed. comp. S. Bocharov. Note S. Bocharova and S. Averintseva. M.: Art. P. 9-191.

5. Bakhtin, M. (1986) Aesthetics of verbal creativity: 2'nd ed.; comp. S. Bocharov; approx. S. Averintseva and S. Bocharova. M.: Art. 445 p.

6. Bonfeld, M. (1991) Music. Language. Speech. Thinking: (Experience of systematic analysis of musical art). Part 1. Abstracts. M.: MGZPI. $125 \mathrm{p}$.

7. Vygotsky, L. (1968) Psychology of art. M.: Art. 576 p.

8. Vygotsky, L. (1999) Thinking and speech: Ed. 5, ref. M.: Labyrinth. $352 \mathrm{p}$.

9. Gadamer, H.-G. (1988) Truth and method. Fundamentals of philosophical hermeneutics. M.: Progress. $637 \mathrm{p}$.

10. Maturana, U., Varela, F. (2001) The tree of knowledge: The biological roots of human understanding. Trans. in English Y.A. Danilova. M.: Progress-Tradition. 224 p.

11. Martinyuk, A.P. (2011) Dictionary of basic terms of cognitivediscursive linguistics. H.: VN KhNU Karazina. 196 p. $440 \mathrm{p}$.

12. Orlov, G. (2005) The tree of music. 2'nd ed. SPb.: Composer. 